\title{
A comparative analysis of operational efficiency between Chinese and Indian commercial banks
}

\author{
Nan ZHU, Huajie ZHANG \\ Southwestern University of Finance and Economics, Chengdu, China
}

\begin{abstract}
:
Aim: The objective of this paper is to make comparative analysis on operational efficiency between Chinese and Indian commercial banks (CBs).

Design / Research methods: Following the previous scholars' study, two models with different sets of input and output variables have been used to show how efficiency scores vary with change in inputs and outputs. The efficiency scores are measured by using data envelopment analysis (DEA) approach.
\end{abstract}

Conclusions / findings: The mean technical efficiency score of Chinese CBs is always relatively higher than the corresponding score of Indian CBs in 2012-2013, respectively. In terms of technical efficiency and pure technical efficiency, the performance of foreign banks in China is always relatively lower than that of foreign banks in India.

Originality / value of the article: While many similar studies have evaluated the performance of banking industries in different countries, very few studies have evaluated the performance of banking sectors between Chinese and Indian economies. The paper would be of interest for OR scholars and practitioners in financial industry.

Implications of the research (if applicable): The next step of this study could collect more samples and use Malmquist index method to conduct further study on efficiency, efficiency changing and productivity, in order to conduct further competitive power analysis on both of banking industries of China and India.

Key words: Data envelopment analysis, Commercial banks, China, India.

Correspondence address: Nan ZHU, Huajie ZHANG, Southwestern University of Finance and Economics, Chengdu 610074, China E-mail: . zhunan@swufe.edu.cn, 111020209001@2011.swufe.edu.cn

Received: 30.08.2017, Revised: 07.11.2017, Revised: 04.07.2018, Accepted: 04.07.2018

Doi: http://dx.doi.org/10.29015/cerem.535 


\section{Introduction}

Organization management gets people together for organizational strategic objectives and enables the optimal use of scarce resources through planning, organizing, leading and control at the workplace. Usually, a commercial bank (CB), which is a special service organization, is a type of financial intermediary and of bank that provides services such as accepting deposits, making business loans, and offering basic investment products. Banks are vital organizations in any country as they significantly contribute to the development of an economy through serving customers, and play the major role in economic development.

The objective of this paper is to make comparative analysis of operational efficiency between Chinese and Indian CBs by using data envelopment analysis (DEA) approach introduced by Charnes, Cooper and Rhodes (1978). While many similar studies have evaluated the performance of banking industries in different countries, very few studies have evaluated the performance of banking sectors between Chinese and Indian economies.

Both of China and India belong to developing countries. They are the two most populous countries and fastest growing major economies in the world. In this paper, following the previous scholars' study and using DEA method, with available published data and by setting up two models, we make comparative analysis of operational efficiency (including technical efficiency, pure technical efficiency and scale efficiency) between Chinese and Indian CBs for the span of two years, 2012 and 2013, respectively.

The paper is organized as follows. A brief review of the current state of the Chinese and Indian banking sector is provided in Section 2. In Section 3 methodology is discussed. Section 4 presents the results and Section 5 concludes this paper. 


\section{A brief overview of the Chinese and Indian banking industry}

China and India are separated by the geographical obstacles of the Himalayas. The China's population of in 2013 is about 1.36 billion. India is the second-most populous country over 1.2 billion people. Historically, China and India have had relations for more than 2,000 years. On 1 January 1950, the People's Republic of China established diplomatic relations with the Republic of India. Since then the bilateral economic relationship has been increased significantly.

In China, the CBs are those enterprise legal persons which are established to absorb public deposits, make loans, arrange settlement of accounts and engage in other businesses. CBs shall work under the principles of safety, liquidity and efficiency, with full autonomy and assume sole responsibility for their own risks, profits and losses, and with self-restraint. At the end of 2013, the Chinese banking industry had 3,949 financial institutions with 3.55 million employees. The banks include: 5 large and state-owned CBs (Industrial \& Commercial Bank of China, China Construction Bank, Agricultural Bank of China, Bank of China and Bank of Communications), 12 joint-stock CBs, 145 city CBs, 468 rural CBs, 122 rural cooperative banks, 1,803 rural credit cooperatives, one postal savings bank and 42 foreign financial institutions, etc. (China Banking Regulatory Commission 2014).

Since July 2013, the Chinese banks have been free to set their own lending rates. In comparison to their counterparts, the 5 state-owned $\mathrm{CBs}$ exhibit strong capabilities and competitiveness compared to either in terms of financial indicators: such as asset scale and profitability. E.g., at the end of 2013, the total sum of assets of 5 big banks is RMB 11.254 trillion (US\$ 1.844 trillion), hold $43.34 \%$ of total financial asset of the Chinese banking financial institutions (China Banking Regulatory Commission 2014).

The Indian banking industry is broadly classified into scheduled banks and nonscheduled banks. The scheduled banks are further classified into: State Bank of India and its associates; nationalized banks; Indian private sector banks; foreign banks; and regional rural banks. Generally banking in India is fairly mature in terms of supply, product range and reach-even though reach in rural India. The term CBs in India refers to both scheduled and non-scheduled CBs. The CBs are consisted of 
public sector CBs, private sector CBs and foreign CBs. Public sector CBs are owned and operated by the government as the government holds a major share in them. A well-operated public sector $\mathrm{CB}$ can help state and local governments in getting through cash crunches. The Indian government presently hires the CBs for different purposes like tax collection and refunds, payment of pensions, etc. (Reserve Bank of India 2014).

By 2013 the Indian Banking Industry employed 1.18 million employees and had a total of 109,811 branches in India and 171 branches abroad and manages an aggregate deposit of ₹67,504.54 billion (US\$1.1 trillion) and bank credit of $₹ 52,604.59$ billion (US\$820 billion). During the financial year Mar 2013-Mar 2014, there were 27 public sector CBs in India out of which 6 were State Bank of India and its 5 associates banks (State Bank of Bikaner and Jaipur, State Bank of Hyderabad, State Bank of Mysore, State Bank of Patiala and State Bank of Travancore), and 21 were nationalized CBs. At the same time, there were 20 private sector $\mathrm{CBs}, 43$ foreign $\mathrm{CBs}$, regional rural banks, cooperative banks, other type banks and financial institutions in India. On the performance of Indian scheduled $\mathrm{CBs}$, in terms of consolidated operations, the consolidated balance sheet of the CBs in 2013-2014 registered a decline in growth in total assets and credit for the fourth consecutive year. With both credit and deposit growth more or less same, the outstanding credit to deposit ratio at the aggregate level remained unchanged at around 79\% (Reserve Bank of India 2014).

\section{Methodology}

\subsection{Data envelopment analysis}

Charnes, Cooper and Rhodes (1978) introduced DEA as non-parametric efficiency analysis for measuring the efficiency of Decision Making Units (DMUs). Consider a set of $J$ decision-making units (DMUs) with $n$ input and $m$ output in $T$ $(t=1, \ldots, T)$ periods. Assume in time period $t$, decision-makers are using inputs $x^{t} \in R_{+}^{n}$, to produce outputs $y^{t} \in R_{+}^{m}$. Define the input requirement set in period $t$, which is: 


$$
L^{t}\left(y^{t}\right)=\left\{x^{t}: x^{t} \text { can produce } y^{t}\right\}
$$

Assume that $L^{t}\left(y^{t}\right)$ is non-empty, closed, convex, bounded and satisfies strong disposability property of inputs and outputs. $L^{t}\left(y^{t}\right)$ is bounded from below by the input isoquant (a constant returns to scale (CRS) production boundary), that is:

$$
\operatorname{Isoq} L^{t}\left(y^{t}\right)=\left\{x^{t}: x^{t} \in L^{t}\left(y^{t}\right), \lambda x^{t} \notin L^{t}\left(y^{t}\right) \text { for } \lambda<1\right\} .
$$

Define the input distance function of period $t$ as following:

$$
D^{t}\left(y^{t}, x^{t}\right)=\sup _{\theta}\left\{\theta:\left(x^{t} / \theta\right) \in L^{t}\left(y^{t}\right), \quad \theta>0\right\} .
$$

Hence, define the technical (or productive) efficiency (TE) in period $t$ as following:

$$
\operatorname{TE}^{t}\left(y^{t}, x^{t}\right)=1 / D^{t}\left(y^{t}, x^{t}\right)
$$

In general, $\mathrm{TE}<1$, indicates that the DMU under assessment, comparing with other DMUs, is productively inefficient since its production is based on excessive input usage. $\mathrm{TE}=1$, indicates the $\mathrm{DMU}$ is fully productively efficient.

It is well known that TE can be further decomposed into the pure technical efficiency (PTE) and scale efficiency (SE) (Banker et al. 1984):

$$
\mathrm{TE}=\mathrm{PTE} \times \mathrm{SE} \text {. }
$$

In general, as TE, PTE or $\mathrm{SE}<1$, indicates that the DMU under assessment, comparing with other DMUs, is pure technically inefficient or scale inefficient.

Following the above DEA models, many theoretical studies as well as applications are surveyed (Emrouznejad, De Witte 2010; Emrouznejad, Yang 2018). At present, the DEA models and development with applications in banking and finance areas can be seen. See, for examples, Emrouznejad and Anouze (2010), Hada and Tamang (2014), Wanke et al. (2016, 2017), and Zhu et al. (2017). 


\subsection{Two input-output models and solving}

In the banking sector, Avkiran (1999), Sathye (2003) measured the productive efficiency (PE, i.e. TE) of banks in Australia and India by using DEA approach, respectively. Two input-output models, i.e., Model A and Model B, in their studies, have been constructed and used to show how efficiency scores vary with change in inputs and outputs. Following the same study direction, Zhu et al. (2004, 2012) studied the TE of Chinese main CBs by using the similar input-output DEA models, respectively; Recently, Hada et al. (2017) conducted a study on the productive efficiency between Nepal and China banking industry in year 2012 and 2013.

In this paper, following the previous scholars' work, two models, i.e., Model A and Model B, are provided and used:

\begin{tabular}{|l|l|l|}
\hline & Model A & Model B \\
\hline Inputs & Interest expense & Deposits \\
& Non-interest expense & Staff numbers \\
\hline Outputs & Net interest income & Net loans \\
& Non-interest income & Non-interest income \\
\hline
\end{tabular}

Data used in this study is gathered from Bankscope database and annual reports of the banks from 2012 to 2013. Through data cleansing, we have got the samples of 100 Chinese CBs and 53 Indian CBs in 2012 and 2013. Chinese samples consist of 5 state-owned CBs, 12 joint-stock CBs, 54 city CBs, 15 rural CBs and 14 foreign CBs in China. Indian samples consist of State Bank of India and its 5 associates, 19 nationalized CBs, 19 private sector CBs, 4 foreign CBs in India (Citibank, HSBC, Standard Chart Bank and Bank of America) and 5 other type CBs in India.

The DEA problems are solved in the paper using the computer software DEASolver. The operational efficiency given is calculated in the input-oriented measure.

\section{Results}

The DEA results of the analysis are discussed in the following. Table 1 shows that by using the two DEA models, the mean operational efficiency score of all 153 sample CBs in 2012 and 2013, respectively. 
Through Table 1, we see that the mean technical efficiency (TE) scores of the whole 153 banking samples collected from both of China and India, obtained by using both Model A and Model B, are slightly increased from 2012-2013. The mean scale efficiency (SE) scores are always relatively higher than the mean pure technical efficiency (PTE) scores.

Table 1. Mean operational efficiency score

\begin{tabular}{|c|c|c|c|c|c|c|}
\hline Model A & 2013 TE & 2013 PTE & $\mathbf{2 0 1 3 ~ S E}$ & $\mathbf{2 0 1 2}$ TE & 2012 PTE & 2012 SE \\
\hline All 153 & 0.6609 & 0.7277 & 0.9146 & 0.6502 & 0.7487 & 0.8712 \\
\hline $\begin{array}{c}\text { China All } \\
\mathbf{1 0 0}\end{array}$ & 0.7465 & 0.8052 & 0.9297 & 0.7323 & 0.8208 & 0.8968 \\
\hline $\begin{array}{c}\text { India All } \\
\mathbf{5 3}\end{array}$ & 0.4993 & 0.5816 & 0.8862 & 0.4953 & 0.6126 & 0.8229 \\
\hline Model B & $\mathbf{2 0 1 3} \mathbf{~ T E}$ & $\mathbf{2 0 1 3}$ PTE & $\mathbf{2 0 1 3}$ SE & $\mathbf{2 0 1 2} \mathbf{~ T E}$ & $\mathbf{2 0 1 2}$ PTE & $\mathbf{2 0 1 2}$ SE \\
\hline All 153 & 0.6823 & 0.7526 & 0.9150 & 0.6719 & 0.7431 & 0.9115 \\
\hline $\begin{array}{c}\text { China All } \\
\mathbf{1 0 0}\end{array}$ & 0.6914 & 0.7521 & 0.9272 & 0.7057 & 0.7519 & 0.9448 \\
\hline $\begin{array}{c}\text { India All } \\
\mathbf{5 3}\end{array}$ & 0.6651 & 0.7536 & 0.8921 & 0.6081 & 0.7265 & 0.8488 \\
\hline
\end{tabular}

Source: authors' own elaboration

Comparative analysis could be made. Mean TE score of Chinese CBs is relatively higher than the corresponding score of Indian CBs except PTE score of Model B in $2013(0.7521<0.7536)$. Using Formula (2): TE $=\mathrm{PTE} \times \mathrm{SE}$, we can also make factor analysis on TE. In Table 1, that $\mathrm{PTE}<\mathrm{SE}$ is always true. Thus, the low PTE score brings the low TE score.

In detail, we have Tables 2-4 by using two DEA models. We can make similar comparative analysis through these tables. In Tables 2 and 3, "CH" means China, "CH 5 State" means 5 Chinese state-owned banks, "Joint" means joint-stock bank, "City" means city bank, "Rural" means rural bank, and "Foreign" means foreign bank in China. "IN" means India, "IN 6 State" means State Bank of India and its 5 associates, "National" means nationalized bank, "IN 24 General" means 19 private sector banks and 5 other type CBs in India, and "Foreign" means foreign bank in India. In Table 4, "IN 25 Public" means State Bank of India and its 5 associates, and 19 nationalized banks, "Private" means private sector banks, and "Others" means other type CBs in India. 
Through Tables 2-3, we see that, in terms of TE and PTE, the performance of China's 5 state-owned banks is relatively higher than that of State Bank of India and its 5 associates, and China's other CBs; however, in term of SE, the performance of China's 5 state-owned banks is always relatively lower than that of State Bank of India and its 5 associates, and China's other CBs, respectively. However, in terms of TE and PTE, the performance of foreign banks in China is always relatively lower than that of foreign banks in India.

Table 2. Mean operational efficiency score of Model A

\begin{tabular}{|c|c|c|c|c|c|c|}
\hline Model A & 2013 TE & 2013 PTE & 2013 SE & 2012 TE & 2012 PTE & 2012 SE \\
\hline $\begin{array}{c}\text { CH 5 } \\
\text { State }\end{array}$ & 0.8409 & 0.9741 & 0.8632 & 0.7734 & 0.9816 & 0.7872 \\
\hline $\begin{array}{c}\text { CH 95 } \\
\text { Others }\end{array}$ & 0.7415 & 0.7963 & 0.9332 & 0.7301 & 0.8123 & 0.9025 \\
\hline $\begin{array}{c}\text { CH 12 } \\
\text { Joint }\end{array}$ & 0.7252 & 0.8597 & 0.8460 & 0.6460 & 0.8630 & 0.7504 \\
\hline $\begin{array}{c}\text { CH 54 } \\
\text { City }\end{array}$ & 0.7805 & 0.8155 & 0.9582 & 0.7481 & 0.8120 & 0.9236 \\
\hline $\begin{array}{c}\text { CH 15 } \\
\text { Rural }\end{array}$ & 0.7419 & 0.7893 & 0.9414 & 0.7974 & 0.8652 & 0.9233 \\
\hline $\begin{array}{c}\text { CH 14 } \\
\text { Foreign }\end{array}$ & 0.6044 & 0.6756 & 0.9023 & 0.6607 & 0.7131 & 0.9293 \\
\hline IN 6 State & 0.4297 & 0.4542 & 0.9525 & 0.4145 & 0.5163 & 0.8091 \\
\hline $\begin{array}{c}\text { IN 47 } \\
\text { Others }\end{array}$ & 0.5082 & 0.5979 & 0.8777 & 0.5056 & 0.6249 & 0.8247 \\
\hline $\begin{array}{c}\text { IN 19 } \\
\text { National }\end{array}$ & 0.4732 & 0.5143 & 0.9275 & 0.4531 & 0.5805 & 0.7878 \\
\hline $\begin{array}{c}\text { IN 24 } \\
\text { General }\end{array}$ & 0.4847 & 0.6157 & 0.8314 & 0.4881 & 0.6076 & 0.8392 \\
\hline $\begin{array}{c}\text { IN 4 } \\
\text { Foreign }\end{array}$ & 0.8160 & 0.8880 & 0.9189 & 0.8591 & 0.9403 & 0.9127 \\
\hline
\end{tabular}

Source: authors' own elaboration

For Chinese CBs, by using Model B, Zhu et al. (2004) discussed two groups of Chinese CBs for the years 2000-2001, that is, state-owned banks and joint-stock banks, and obtained that the mean TE score of state-owned banks is relatively lower than that of joint-stock banks in 2000 and 2001, respectively. For the years 20122013, through Table 3 that is the result by using Model B, we can see that the mean TE score of state-owned banks is still relatively lower than that of joint-stock banks, respectively. However, through Table 2 that is the result by using Model A, we can 
see that the mean TE score of state-owned banks is relatively higher than that of joint-stock banks in 2012-2013, respectively, that are the opposite results.

Table 3. Mean operational efficiency score of Model B

\begin{tabular}{|c|c|c|c|c|c|c|}
\hline Model B & 2013 TE & 2013 PTE & 2013 SE & 2012 TE & 2012 PTE & 2012 SE \\
\hline $\begin{array}{c}\text { CH 5 } \\
\text { State }\end{array}$ & 0.7342 & 0.9537 & 0.7655 & 0.7234 & 0.9542 & 0.7545 \\
\hline $\begin{array}{c}\text { CH 95 } \\
\text { Others }\end{array}$ & 0.6891 & 0.7415 & 0.9357 & 0.7047 & 0.7412 & 0.9548 \\
\hline $\begin{array}{c}\text { CH 12 } \\
\text { Joint }\end{array}$ & 0.8414 & 0.9269 & 0.9086 & 0.8672 & 0.9377 & 0.9257 \\
\hline $\begin{array}{c}\text { CH 54 } \\
\text { City }\end{array}$ & 0.6447 & 0.6814 & 0.9533 & 0.6562 & 0.6810 & 0.9677 \\
\hline $\begin{array}{c}\text { CH 15 } \\
\text { Rural }\end{array}$ & 0.7148 & 0.7582 & 0.9392 & 0.7150 & 0.7632 & 0.9374 \\
\hline $\begin{array}{c}\text { CH 14 } \\
\text { Foreign }\end{array}$ & 0.7025 & 0.7962 & 0.8874 & 0.7415 & 0.7813 & 0.9488 \\
\hline $\begin{array}{c}\text { IN 6 } \\
\text { State }\end{array}$ & 0.6790 & 0.7406 & 0.9316 & 0.6101 & 0.7166 & 0.8714 \\
\hline $\begin{array}{c}\text { IN 47 } \\
\text { Others }\end{array}$ & 0.6633 & 0.7553 & 0.8871 & 0.6078 & 0.7278 & 0.8459 \\
\hline $\begin{array}{c}\text { IN 19 } \\
\text { National }\end{array}$ & 0.6455 & 0.7467 & 0.8718 & 0.5936 & 0.7488 & 0.7983 \\
\hline $\begin{array}{c}\text { IN 24 } \\
\text { General }\end{array}$ & 0.6641 & 0.7392 & 0.9076 & 0.5917 & 0.6794 & 0.8859 \\
\hline $\begin{array}{c}\text { IN 4 } \\
\text { Foreign }\end{array}$ & 0.7427 & 0.8928 & 0.8364 & 0.7723 & 0.9178 & 0.8323 \\
\hline Sour a & 0.7578 & & \\
\hline
\end{tabular}

Source: authors' own elaboration

For Indian CBs, by using Model A and Model B, Sathye (2003) discussed three groups of Indian banks for the year 1997, that is, publicly owned, privately owned and foreign owned, and obtained that the mean efficiency score of Indian banks compares well with the world mean efficiency score and the efficiency of private sector banks as a group is, paradoxically lower than that of public sector banks and foreign banks in India. However, through Table 4 in this paper, we can see that the TE score of private sector banks in India as a group is always higher than that of 
public sector banks; however, always lower than foreign banks in India in 2012 and 2013, respectively.

Table 4. Mean operational efficiency score of Indian banking industry

\begin{tabular}{|c|c|c|c|c|c|c|}
\hline Model A & 2013 TE & 2013 PTE & $2013 \mathrm{SE}$ & 2012 TE & 2012 PTE & $2012 \mathrm{SE}$ \\
\hline $\begin{array}{l}\text { IN } 25 \\
\text { Public }\end{array}$ & 0.4627 & 0.4999 & 0.9335 & 0.4439 & 0.5651 & 0.7929 \\
\hline $\begin{array}{c}\text { IN } 19 \\
\text { Private }\end{array}$ & 0.4826 & 0.5560 & 0.8913 & 0.4990 & 0.5733 & 0.8913 \\
\hline IN 5 Others & 0.4927 & 0.8423 & 0.6037 & 0.4468 & 0.7378 & 0.6413 \\
\hline $\begin{array}{c}\text { IN } 4 \\
\text { Foreign }\end{array}$ & 0.8160 & 0.8880 & 0.9189 & 0.8591 & 0.9403 & 0.9127 \\
\hline India All 53 & 0.4993 & 0.5816 & 0.8862 & 0.4953 & 0.6126 & 0.8229 \\
\hline Model B & 2013 TE & 2013 PTE & $2013 \mathrm{SE}$ & 2012 TE & 2012 PTE & $2012 \mathrm{SE}$ \\
\hline $\begin{array}{l}\text { IN } 25 \\
\text { Public }\end{array}$ & 0.6536 & 0.7452 & 0.8861 & 0.5976 & 0.7411 & 0.8159 \\
\hline $\begin{array}{c}\text { IN } 19 \\
\text { Private }\end{array}$ & 0.6944 & 0.7261 & 0.9587 & 0.6256 & 0.6679 & 0.9435 \\
\hline IN 5 Others & 0.5489 & 0.7889 & 0.7133 & 0.4627 & 0.7231 & 0.6670 \\
\hline $\begin{array}{c}\text { IN } 4 \\
\text { Foreign }\end{array}$ & 0.7427 & 0.8928 & 0.8364 & 0.7723 & 0.9178 & 0.8323 \\
\hline India All 53 & 0.6651 & 0.7536 & 0.8921 & 0.6081 & 0.7265 & 0.8488 \\
\hline
\end{tabular}

Source: authors' own elaboration

\section{Conclusion}

China and India are two of the world's oldest civilizations and have co-existed in peace for millennia. In this paper, we make comparative analysis of operational efficiency between Chinese and Indian CBs in 2012 and 2013 by using DEA 
approach. Two DEA output-input models, i.e. Model A and Model B, have been used to show how efficiency scores vary with change in inputs and outputs.

We have that mean technical efficiency score of Chinese CBs is always relatively higher than the corresponding score of Indian CBs in 2012-2013, respectively. In terms of technical efficiency and pure technical efficiency, the performance of China's 5 state-owned banks is higher than that of India's State Bank of India and its 5 associates, and China's other CBs, respectively; however, in term of scale efficiency, the performance of China's 5 state-owned banks is relatively lower than that of State Bank of India and its 5 associates, and China's other CBs, respectively. In terms of technical efficiency and pure technical efficiency, the performance of foreign banks in China is always relatively lower than that of foreign banks in India. The performance of private sector banks in India as a group is always relatively higher than that of public sector banks in India; however, lower than that of foreign banks in India.

The next step of this study could collect more samples and use Malmquist index method to conduct further study on efficiency, efficiency changing and productivity, in order to conduct further competitive power analysis on both of banking industries of China and India.

Acknowledgments: We would like to thank to two anonymous reviewers for their insightful comments and suggestions on this paper.

\section{References}

Avkiran N.K. (1999), The evidence of efficiency gains. The role of mergers and the benefits to the public, ,Journal of Banking and Finance”, vol. 23 no. 7, pp. 991-1013.

Banker R.D., Charnes A., Cooper W.W. (1984), Some models for estimating technical and scale inefficiencies in Data Envelopment Analysis, „Management Science”, vol. 30 no. 9, pp. 1078-1092.

Charnes, A., Cooper W.W., Rhodes E. (1978), Measuring the efficiency of decision making units, „European Journal of Operational Research”, vol. 2 no. 6, pp. 429-444.

Cooper W.W., Seiford L.M., Tone K. (1999), Data Envelopment Analysis, a comprehensive text with models, applications, references and DEA-solver software, Kluwer Academic Publishers, Boston.

China Banking Regulatory Commission (2014), Annual Report 2013, China CITIC Press, Beijing. 
Emrouznejad A., Anouze A.L. (2010), Data Envelopment Analysis with classification and regression tree. A case of banking efficiency, „Expert Systems”, vol. 27 no. 4, pp. 231-246.

Emrouznejad A., De Witte K. (2010), COOPER-framework. A unified process for non-parametric projects, „European Journal of Operational Research”, vol. 207 no. 3, pp. 1573-1586.

Emrouznejad A., Yang G. (2018), A survey and analysis of the first 40 years of scholarly literature in DEA: 1978-2016, „Journal of Socio-Economic Planning Sciences”, vol. 61 no. 1, pp. 1-5.

Hada S.S., Tamang G. (2014), Frontier analysis of Nepalese commercial banks. DEA Approach, „Journal of Mathematics and System Science”, no. 4, pp. 675-682.

Hada S.S., Zhu N., Tamang G. (2017), Frontier analysis of Nepalese and Chinese commercial banks. DEA approach, „International Journal of Operational Research - Nepal”, no. 1, pp. 39-46.

Sathye M. (2003), Efficiency of banks in a developing economy. The case of India, „European Journal of Operational Research", vol. 148 no. 3, pp. 662-671.

Reserve Bank of India (2014), Financial stability report (Including trend and progress of banking in India 2013-2014), https://rbidocs.rbi.org.in/rdocs/Publications/PDFs/OFLTP577BF4E172064685A26A73A6BC9210EC.P DF [03.09.2018].

Wanke P.F., Barros C.P., Emrouznejad A. (2016), Assessing productive efficiency of banks using integrated Fuzzy-DEA and bootstrapping. A case of Mozambican banks, „European Journal of Operational Research", vol. 249 no. 1, pp. 378-389.

Wanke P.F., Barros C.P., Emrouznejad A. (2017), A comparison between stochastic DEA and Fuzzy DEA approaches. Revisiting efficiency in Angolan banks, „RAIRO-Operations Research”, vol. 52 no. 1, pp. 285-303.

Zhu N., Li J., Wu Q., Cheng W.L. (2012), On productive efficiency and TFP changes of Chinese commercial banks, „Economist (Jing Ji Xue Jia)”, no. 9, pp. 56-61 (in Chinese).

Zhu N., Liu Y., Emrouznejad A., Huang Q. (2017), An allocation Malmquist index with an application in the China securities industry, „Operational Research - An International Journal”, vol. 17 no. 2, pp. 669-691.

Zhu N., Zhuo X, Dong Y. (2004), A case study of the efficiency of China's national commercial banks and the reform strategy, „Management World”, no. 2, pp. 18-26 (in Chinese). 